\title{
CARBON CREDIT DAN FAKTOR-FAKTOR LAIN YANG BERPENGARUH TERHADAP KINERJA PERUSAHAAN PADA PERUSAHAAN MANUFAKTUR
}

\author{
RIKI SANJAYA \\ Trisakti School of Management \\ Riki_Sanjaya12@yahoo.com
}

\begin{abstract}
The objectives of this research is to test and analyze whether growth opportunities, firm size, cash ratio, firm age, carbon credit, debt ratio and nondebt tax shield have influence to firm performance. This study was also to find something new which seldom to do with researchers in Indonesian about carbon credit and improve consistency of results from prior researchers. Sample in this research are manufacturing companies with industry classification basic industry and chemicals, which are listed from December 2010 until December 2015 in Indonesian Stock Exchange with research time period from 2010 until 2015. Only 40 companies meet the criteria and taken as samples. The samples of this research collected using purposive sampling. This research used multiple regression. The result of this research show that firm size and debt ratio influence firm performance on manufacturing companies with industry classification basic industry and chemicals listed in Indonesian Stock Exchange. On the other hand growth opportunities, cash ratio, firm age, carbon credit and non-debt tax shield not influence firm performance. While simultaneously, all the variables in this research influence firm performance.
\end{abstract}

Keywords: firm performance, carbon credit, basic industry, firm size, debt ratio

\begin{abstract}
Abstrak: Tujuan penelitian adalah untuk menguji dan menganalisa apakah peluang pertumbuhan, ukuran perusahaan, rasio kas, umur perusahaan, kredit karbon, rasio hutang dan perlindungan pajak selain hutang memiliki pengaruh terhadap kinerja perusahaan. Penelitian ini juga untuk mencari fakta yang cukup baru karena masih jarang dilakukan oleh peneliti-peneliti di Indonesia mengenai kredit karbon dan meningkatkan konsistensi dari hasil penelitian sebelumnya. Sampel dari penelitian ini adalah perusahaan manufaktur dengan klasifikasi industri yaitu industri dasar dan bahan kimia, yang sudah terdaftar dari Desember 2010 sampai Desember 2015 pada Bursa Efek Indonesia dengan periode penelitian dari tahun 2010 sampai 2015. Hanya 40 perusahaan yang memenuhi kriteriakriteria dan digunakan dalam sampel. Sampel-sampel dari penelitian ini dikumpulkan dengan metode purposive sampling. Penelitian ini menggunakan analisis regresi berganda. Hasil penelitian menunjukkan bahwa ukuran perusahaan dan rasio hutang berpengaruh terhadap kinerja perusahaan pada perusahaan
\end{abstract}




\begin{abstract}
manufaktur dengan klasifikasi industri yaitu basic industry and chemicals yang terdaftar di Bursa Efek Indonesia. Dengan kata lain peluang pertumbuhan, rasio kas, umur perusahaan, kredit karbon dan perlindungan pajak selain hutang tidak berpengaruh terhadap kinerja perusahaan. Secara simultan, seluruh variabelvariabel dalam penelitian ini berpengaruh terhadap kinerja perusahaan.
\end{abstract}

Kata Kunci: kinerja perusahaan, kredit karbon, industri dasar, ukuran perusahaan, rasio hutang

\section{PENDAHULUAN}

Tujuan utama sebuah perusahaan adalah untuk mencapai profit tetapi seiring dengan perkembangan zaman, perusahaan berusaha untuk membantu people dan juga menjaga planesecara optimal. Tujuan tersebut dapat dicapai jika perusahaan mempunyai kinerja yang maksimal. Setiap Perusahaan yang ada akan berusaha meningkatkan kinerjanya secara maksimal. Untuk itu perlu menganalisa faktor faktor yang berpengaruh terhadap kinerja perusahaan agar tujuan-tujuan perusahaan dapat tercapai, selain itu isu-isu mengenai profit, people dan plane menarik untuk diteliti dengan proxy carbon credit yang dipreposisikan akan berpengaruh terhadap kinerja perusahaan.

Penelitian ini merupakan replikasi dari penelitian Hatem (2014). Kontribusi dari penelitian ini adalah penambahan tiga variabel independen yaitu carbon credit; Debt Ratio dan Non-debt Tax Shield selain itu carbon credit saat ini masih merupakan preposisi karena penelitian ini masih terkategori baru dan teori-teori yang mendasarinya masih sedikit dan belum kuat, yang meneliti pengaruh carbon credit terhadap kinerja perusahaan. Pada penelitian Hatem (2014) menggunakan tahun pengamatan 2003 sampai 2011 sedangkan penelitian ini menggunakan tahun pengamatan 2010 sampai 2015. Penambahan variabel carbon credit didasarkan pada isu-isu saat ini, dimana banyak perusahaan berusaha untuk memaksimalkan profit, plane dan people. Carbon credit disebut juga CER (Certified Emission Reduction) dimana setiap unit CER adalah setara dengan pengurangan 1 ton metrik dari $\mathrm{CO}_{2}$. CER diperoleh dengan melakukan pengurangan GHG (Green House Gas) melalui CDM (Clean Development Management) karena dapat dipertukarkan antara satu perusahaan dengan perusahaan lain dan antara satu negara dengan negara lain melalui carbon market (Mondal dan Sachdev 2012).

CER yang telah diperoleh perusahaan dapat diperjualbelikan sehingga mendapat pendapatan dari World Bank dansisi legitimacy theory, dimana perusahaan akan mendapatkan dukungan dari stakeholder melalui image positif yang dihasilkan, dengan demikian perusahaan yang melakukan pengurangan GHG akan lebih didukung oleh para stakeholdernya misalnya ada customer yang cenderung menggunakan produk-produk yang ramah lingkungan, sehingga carbon credit berpengaruh positif terhadap kinerja perusahaan karena akan selain memperoleh pendapatan dari penjualan CER yang akan berpengaruh langsung ke net income perusahaan dan image positif yang akan didukung oleh para stakeholdernya yang pada akhirnya meningkatkan kinerja perusahaan. Penelitian ini menggunakan sampel yang dikhususkan untuk carbon credit yaitu basic industry dan chemicals karena industri tersebut paling banyak menghasilkan carbon dibandingkan dengan industri lain. Hidayat (2013) menyatakan bahwa beberapa sektor industri masih menghasilkan gas karbon dioksida $\left(\mathrm{CO}_{2}\right)$ yang tinggi, industri tersebut adalah semen, baja, tekstil, petrokimia, pupuk, pulp dan kertas. Diharapkan dengan dipilihnya 
basic industry dan chemicals akan menghasilkan penelitian yang signifikan.

Kinerja Perusahaan adalah hal yang sangat penting bagi perusahaan karena kinerja perusahaan yang optimal dapat memudahkan perusahaan dalam mencapai tujuan tujuan perusahaan seperti mecapai profit optimal, membantu people dan menjaga plane. Secara logika perusahaan yang lebih mapan secara kinerja perusahaanlah yang mampu mencapai profit optimal, yang dapat lebih membantu pihak-pihak lain dan dapat lebih membantu menjaga dunia dari pemanasan global. Selain itu ingin memperoleh bukti empiris mengenai pengaruh carbon credit terhadap kinerja perusahaan, hal-hal ini menjadi dorongan dalam penelitian ini untuk melakukan studi mengenai kinerja perusahaan. Adapun yang menjadi permasalah dalam penelitian ini adalah apakah growth opportunities, firm size, cash ratio, firm age, carbon credit, debt ratio dan non debt tax shield berpengaruh terhadap kinerja perusahaan. Dari permasalah penelitian tersebut maka tujuan penelitian ini adalah mendapatkan bukti empiris mengenai pengaruh growth opportunites, firm size, cash ratio, firm age, carbon credit, debt ratio dan non debt tax shield terhadap kinerja perusahaan.

\section{Legitimacy Theory}

Perusahaan-perusahaan akan cenderung meningkatkan kinerja dan kelestarian lingkungan dan pengungkapan informasi lingkungan untuk melegitimasi aktivitasaktivitasnya agar sesuai sudut pandang yang dimiliki oleh masyarakat luas. Teori legitimasi lebih memfokuskan pada interaksi antara perusahaan dengan masyarakat luas. Perusahaan akan berusaha menciptakan harmonisasi antara nilai-nilai sosial yang tersirat didalam kegiatan usahanya dengan normanorma perilaku yang sudah ada dalam sistem sosial masyarakat dimana organisasi merupakan bagian dalam sistem tersebut. Jika kedua sistem nilai tersebut berjalan secara harmonis maka hal tersebut adalah sebagai legitimasi perusahaan (Dowling dan Pfeffer 1975). Gagasan legitimasi bahwa konsep bisnis harus memenuhi persepsi-persepsi relevan yang dimiliki oleh publik dan masyarakat luas (Maryani 2013). Jika perusahaan ingin tetap mendapatkan dukungan dalam masyarakat, perusahaan seharusnya peduli dengan sosial dan lingkungan serta mengungkapkannya dalam annual report (Maryani 2013).

\section{Kinerja Perusahaan}

Kinerja perusahaan menunjukkan seberapa baik suatu perusahaan dalam menjalankan aktivitas-aktivitas untuk mencapai tujuan perusahaan tersebut. Kinerja perusahaan yang baik dapat diukur dengan banyak metode seperti seberapa efisien perusahaan menggunakan asetnya untuk menghasilkan laba.Hatem (2014) menyatakan bahwa kinerja perusahaan dapat diukur dengan menggunakan empat metode yaitu return on assets; return on equity; return on sales dan earnings per share. Kinerja perusahaan yang diukur secara tepat akan dibutuhkan oleh para investor dalam menentukan keputusan investasinya, yang berakibat pada perusahaan itu sendiri, kepada investor dan juga stakeholder lainnya. Semakin tinggi kinerja perusahaan maka semakin mungkin perusahaan tersebut membantu lingkungan dan masyarakat.

\section{Growth Opportunities dan Kinerja Perusahaan}

Growth opportunities merupakan peluang suatu perusahaan untuk dapat bertumbuh yang didapat dilihat dengan perbandingan antara nilai pasar dengan nilai buku ekuitas suatu perusahaan atau market to book ratio (Hatem 2014).Growth opportunities yang ada pada suatu perusahaan dapat menunjukkan proyek investasi yang profitable yang akan berpengaruh positif terhadap kinerja perusahaan (Hatem 2014). Seelanatha (2011) menemukan bahwa growth potential berpengaruh terhadap kinerja perusahaan. Hatem (2014) juga melakukan penelitian dengan hasil growth opportunities 
berpengaruh secara positif dan signifikan terhadap kinerja perusahaan. Memon et al. (2010), Izati dan Margaretha (2014) dan Mehari dan Aemiro (2013) juga menemukan bahwa growth opportunities berpengaruh positif terhadap kinerja perusahaan. Hasil penelitian di atas berbeda dengan Abbas et al. (2013) yang menemukan bahwa growth berpengaruh secara negatif terhadap kinerja perusahaan.Salawu et al. (2012) yang menemukan bahwa growth opportunities berpengaruh secara negatif terhadap kinerja perusahaan.Seetanah et al. (2014), Bashir et al. (2013) dan Tariq et al.(2013) yang menemukan bahwa growth opportunities tidak berpengaruh terhadap kinerja perusahaan.

$\mathrm{H}_{1}$ : Growth Opportunities berpengaruh positif terhadap kinerja perusahaan.

\section{Firm Size dan Kinerja Perusahaan}

Firm size merupakan seberapa besar ukuran suatu perusahaan yang diproksikan dengan beberapa pengukuran contohnya adalah jumlah total aset dan jumlah pendapatan suatu perusahaan. Semakin besar ukuran suatu perusahaan maka akan menimbulkan peluang pertumbuhan yang lebih diminati yang mana akan mempengaruhi secara positif terhadap kinerja perusahaan (Hatem 2014).Seetanah et al. (2014) menemukan bahwa size berpengaruh terhadap kinerja perusahaan. Hatem (2014), Abbas et al. (2013), Almajali et al. (2012), Bashir et al. (2013), Dwaikat dan Queiri (2014), Izati dan Margaretha (2014), Khalifa dan Shafii (2013), Mehari dan Aemiro (2013),Memon et al. (2010), Mirza dan Javed (2013), Pathirawasam dan Wickremasinghe (2012), Singh dan Dhingra (2013) dan Tariq et al. (2013) yang melakukan penelitian dengan hasil firm size berpengaruh secara positif dan signifikan terhadap kinerja perusahaan. Hasil penelitian tersebut berbeda dengan Salawu et al. (2012) dan Seelanatha (2011) yang menemukan bahwa firm size berpengaruh secara negatif terhadap kinerja perusahaan. Wiranata dan Nugrahanti (2013), Fachrudin (2011) dan Talebnia et al. (2010) yang menemukan bahwa firm size tidak berpengaruh terhadap kinerja perusahaan.

$\mathrm{H}_{2}$ : Firm size berpengaruh positif terhadap kinerja perusahaan.

\section{Cash Ratio dan Kinerja Perusahaan}

Cash ratio merupakan perbandingan antara kas dengan total hutang lancar suatu perusahaan. Semakin tinggi cash ratio maka semakin besar kemampuan perusahaan untuk melunasi total hutang lancarnya tetapi keberadaan kas dalam jumlah besar dalam suatu perusahaan membuat manager melakukan masalah investasi yang berlebihan sehingga membuat kinerja perusahaan menurun (Hatem 2014).Izati dan Margaretha (2014) dan Singh dan Dhingra (2013) yang menemukan bahwa liquidity berpengaruh terhadap kinerja perusahaan.Pathirawasam dan Wickremasinghe (2012) dan Seelanatha (2011) yang menemukan bahwa liquidity berpengaruh positif terhadap kinerja perusahaan. Hasil tersebut bertentangan dengan Hatem (2014) melakukan penelitian dengan hasil cash ratio berpengaruh secara negatif dan signifikan terhadap kinerja perusahaan. Khalifa dan Shafii (2013), Almajali et al. (2012) dan Mirza dan Javed (2013) yang menemukan bahwa liquidity berpengaruh negatif terhadap kinerja perusahaan. Bashir et al. (2013), Mehari dan Aemiro (2013) dan Tariq et al. (2013) yang menemukan bahwa liquidity tidak berpengaruh terhadap kinerja perusahaan.

$\mathrm{H}_{3}$ : Cash ratio berpengaruh negatif terhadap kinerja perusahaan.

\section{Firm Age dan Kinerja Perusahaan}

Firm age merupakan seberapa lama suatu perusahaan berdiri. Semakin lama suatu perusahaan berdiri maka reputasi perusahaan tersebut semakin baik sehingga membuat perusahaan dapat meningkatkan profitabilitas dan kinerjanya (Hatem 2014). Singh dan Dhingra (2013) yang menemukan bahwa Age berpengaruh terhadap return on assets. Hatem (2014) yang menemukan bahwa firm age berpengaruh positif dan signifikan terhadap 
kinerja perusahaan. Khalifa dan Shafii (2013) dan Pathirawasam dan Wickremasinghe (2012) juga melakukan penelitian dengan hasil firm age berpengaruh secara positif dan signifikan terhadap kinerja perusahaan. Hasil tersebut bertentangan dengan Almajali et al. (2012), Mehari dan Aemiro (2013), Seetanah et al. (2014) dan Talebnia et al. (2010) yang menemukan bahwa firm age tidak berpengaruh terhadap kinerja perusahaan.

$\mathrm{H}_{4}$ : Firm age berpengaruh positif terhadap kinerja perusahaan.

\section{Carbon Credit dan Kinerja Perusahaan}

Carbon credit adalah pengurangan emisi gas rumah kaca atau GHG (GreenHouse Gas) emissions yang dapat diperdagangkan dan mempunyai nilai ekonomis dan diciptakan berdasarkan legal framework untuk perdagangan emisi seperti Kyoto Protocol atau EU Emissions Trading Scheme maupun dihasilkan oleh tindakan-tindakan sukarela diluar dari legal frameworks tersebut. Dimana pengertian emisi adalah pelepasan gas-gas yang mengandung karbon ke lapisan atmosfer bumi, pelepasan tersebut terjadi karena adanya proses pembakaran terhadap karbon baik dalam bentuk tunggal atau senyawa dapat berbentuk $\mathrm{CO} 2, \mathrm{CH} 4, \mathrm{~N} 2 \mathrm{O}, \mathrm{HFCs}$ dan lain-lain (Kementerian Lingkungan Hidup 2012 dalam Pratiwi dan Sari 2016). Carbon credit berarti pengurangan emisi yang berbahaya terhadap lingkungan dan dunia.

Carbon credit memiliki nama berdasarkan pada scheme dan region (Vijnet al. 2007). Carbon credit memiliki banyak nama tetapi biasanya lebih dikenal dengan istilah CER (Certified Emission Reduction).Perusahaan yang telah melakukan pengurangan emisi maka akan mendapat CER, dengan melakukan pengurangan emisi maka perusahaan akan menjadi good corporate citizen yang akan membawa banyak benefit, termasuk memberikan perusahaan sebuah distinct sense of identity dan meningkatkan positive perceptions oleh employees, customers, suppliers dan other stakeholders yang mengidentifikasi dengan hangat dan bersahabat dari pengungkapan pengurangan emisi karbon yang dilihat pada annual report maupun sustainability report (Arkell 2008). Perusahaan yang memiliki carbon credit kemungkinan akan lebih didukung oleh para stakeholders khususnya investor dan kreditor sehingga investor dan kreditor akan memberikan pendanaan yang lebih besar kepada perusahaan dengan pendanaan yang dikelola dengan baik maka perusahaan dapat meningkatkan kinerjanya (Sanjaya 2014).

$\mathrm{H}_{5}$ : Carbon credit berpengaruh positif terhadap kinerja perusahaan.

\section{Debt Ratio dan Kinerja Perusahaan}

Perusahaan dengan tingkat hutang yang tinggi akan memiliki beban bunga yang tinggi. Beban bunga yang tinggi dengan pendapatan yang relatif tetap akan menyebabkan profit perusahaan lebih kecil, sehingga perusahaan dengan tingkat hutang yang tinggi akan menurunkan kinerja perusahaan. Logika berpikir lainnya perusahaan dengan debt ratio yang tinggi akan membuat insentif kepada manajemen perusahaan dan memaksa manajemen untuk menginvestasikan secara optimal sehingga debt ratio berpengaruh positif terhadap kinerja perusahaan (Almajali et al. 2012).Javed et al. (2014) yang menemukan bahwa debt to asset berpengaruh terhadap kinerja perusahaan.Tariq et al. (2013) yang menemukan bahwa short term leverage berpengaruh terhadap kinerja perusahaan. Salawu et al. (2012), Wiranata dan Nugrahanti (2013), Mehari dan Aemiro (2013), Almajali et al. (2012) dan Bashir et al. (2013) yang menemukan bahwa debt ratio berpengaruh secara positif terhadap kinerja perusahaan. Hasil tersebut bertentangan dengan Izati dan Margaretha (2014), Singh dan Dhingra (2013), Memon et al. (2010) dan Pathirawasam dan Wickremasinghe (2012) yang menemukan bahwa leverage berpengaruh negatif terhadap kinerja perusahaan. Wahla et al. (2012) yang 
menemukan bahwa leverage memiliki hubungan negatif dan signifikan terhadap kinerja perusahaan. Fachrudin (2011) dan Dwaikat dan Queiri (2014) yang menemukan bahwa struktur modal tidak berpengaruh terhadap kinerja perusahaan.

$\mathrm{H}_{6}$ : Debt ratio berpengaruh negatif terhadap kinerja perusahaan.

\section{Non-Debt Tax Shield dan Kinerja Perusahaan}

Perusahaan dengan jumlah aset tetap yang tinggi memiliki nilai depresiasi yang lebih tinggi. Perusahaan dengan beban depresiasi yang tinggi akan mengurangi taxable income perusahaan sehingga jumlah beban pajak lebih rendah, dengan beban pajak lebih rendah maka kinerja perusahaan akan lebih tinggi. Tariq et al. (2013) menemukan bahwa non-debt tax shield berpengaruh terhadap kinerja perusahaan. Abbas et al. (2013) menemukan bahwa nondebt tax shield berpengaruh secara positif terhadap kinerja perusahaan. Bashir et al. (2013) dan Izati dan Margaretha (2014) juga menemukan bahwa non-debt tax shield berpengaruh positif terhadap kinerja perusahaan.

$\mathrm{H}_{7}$ : Non-debt tax shield berpengaruh positif terhadap kinerja perusahaan.

\section{METODA PENELITIAN}

\section{Objek Penelitian}

Adapun yang menjadi populasi dalam penelitian ini adalah perusahaan manufaktur yang terdaftar di Bursa Efek Indonesia pada tahun 2010 sampai 2015. Sampel perusahaan diambil dengan menggunakan metode purposive sampling. Adapun yang menjadi kriteria: perusahaan manufaktur dengan industry classification basic industry and chemical syang terdaftar atau tercatat di Bursa Efek Indonesiadari tahun 2010 sampai 2015; perusahaan tersebut mempublikasikan laporan tahunan dari tahun 2010 sampai 2015di idx.co.id.

\section{Tabel 1 Prosedur Pemilihan Sampel}

\begin{tabular}{clccc}
\hline No & \multicolumn{1}{c}{ Keterangan } & Perusahaan & Tahun & Data \\
\hline 1. & $\begin{array}{l}\text { Perusahaan manufaktur dengan industry classification } \\
\text { basic industry and chemicals yang terdaftar atau tercatat } \\
\text { di BEl dari tahun 2010 sampai 2015 }\end{array}$ & 69 & & \\
2. & $\begin{array}{l}\text { Perusahaan yang tidak mempublikasikan laporan tahunan } \\
\text { dari tahun 2010 sampai 2015 }\end{array}$ & 29 & & \\
3. $\quad \begin{array}{l}\text { Total perusahaan dan data yang digunakan dalam } \\
\text { penelitian }\end{array}$ & 40 & 6 & 240 \\
4. & Data outlier & & & $(11)$ \\
5. & Total data yang digunakan dalam penelitian & & 229 \\
\hline
\end{tabular}

\section{Definisi Operasional Variabel dan Pengukurannya}

Kinerja perusahaan merupakan kemampuan perusahaan dalam menghasilkan laba bersih dari semua aset yang dimiliki perusahaan. Kinerja perusahaan $=$ Net income $I$ Total assets (Hatem 2014).
Growth Opportunities merupakan seberapa besar peluang pertumbuhan suatu perusahaan. Growth opportunities = market to book ratio (MBR) (Hatem 2014). MBR dijelaskan dengan market value of common stocks / book value of common stocks. Dimana market value of common stocks adalah number of shares outstanding $\mathrm{x}$ stock price at end of year dan 
book value of common stocks adalah common stock equity (Wijaya 2012).

Firm Size merupakan seberapa besar ukuran suatu perusahaan. Firm size $=$ logarithm dari total sales (Hastalona 2013).

Cash Ratiomerupakan rasio kas yang dimiliki suatu perusahaan. Cash ratio $=$ cash 1 current liability (Hatem, 2014).

Firm Age merupakan jumlah tahun sejak perusahaan didirikan (Romagos et al. 2012). Firm age = jumlah tahun perusahaan berdiri (Margaretha dan Asmariani 2009).

Carbon Credit merupakan pengurangan emisi gas rumah kaca atau GHG (Green House Gas) emissions yang dapat diperdagangkan dan mempunyai nilai ekonomis dan diciptakan berdasarkan legal framework untuk perdagangan emissions maupun dihasilkan oleh tindakan-tindakan sukarela di luar dari legal framework tersebut. Carbon credit diukur dengan menggunakan pengukuran dummy variabel dimana 1 untuk perusahaan yang memiliki carbon credit dan 0 untuk perusahaan yang tidak memiliki carbon credit. Penentuan perusahaan yang memiliki atau tidak memiliki carbon credit berdasarkan pada adanya pengungkapan atau tidak pada annual report mengenai salah satu GHG items. GHG items diperoleh berdasarkan penggabungan 2 artikel yaitu Rankin et al. (2011) dan Chu et al. (2013) dengan mengeliminasi item-item yang memiliki kesamaan arti.

Tabel 2 Greenhouse Gas Index

\begin{tabular}{|c|c|c|}
\hline No & 7.3.1 & Penjelasan dari GHG Inventory \\
\hline 1 & $\mathrm{~b}$ & Orang yang bertanggung jawab (pihak) \\
\hline 2 & c & Periode perlaporan yang di cover \\
\hline 3 & $d$ & Document organisational boundaries \\
\hline 4 & e & Direct GHG emissions (tonnes of CO2e) \\
\hline 5 & f & $\begin{array}{l}\text { Penjelasan dari bagaimana perlakuan emisi } \mathrm{CO} 2 \text { dari pembakaran tanaman } \\
\text { organik dalam GHG inventory }\end{array}$ \\
\hline 6 & g & If quantified, GHG removals, quantified (tonnes CO2e) \\
\hline 7 & i & $\begin{array}{l}\text { Energy indirect GHG emissions associated with generation of imported electricity, } \\
\text { heat or steam (tonnes CO2e) }\end{array}$ \\
\hline 8 & I\& m & Referensi untuk atau deskripsi dari metodologi kuantifikasi \\
\hline 9 & $\mathrm{n}$ & $\begin{array}{l}\text { Referensi untuk atau dokumentasi dari emisi GHG atau penghapusan faktor-faktor } \\
\text { yang digunakan }\end{array}$ \\
\hline 10 & 0 & $\begin{array}{l}\text { Deskripsi dari dampak dari ketidakpastian pada akurasi dari emisi GHG dan } \\
\text { penghapusan data }\end{array}$ \\
\hline 11 & $\mathrm{p}$ & Pernyataan yang disiapkan yang sesuai dengan ISO 14064 \\
\hline \multirow[t]{2}{*}{12} & $q$ & $\begin{array}{l}\text { Pernyataan yang menjelaskan GHG inventori, laporan atau asersi yang telah } \\
\text { diverifikasi }\end{array}$ \\
\hline & 7.3.2 & Isu - isu lain yang dapat dipertimbangkan \\
\hline 13 & a & Deskripsi dari kebijakan-kebijakan, strategi-strategi dan program-program \\
\hline 14 & f & Emisi GHG atau penghapusan yang dipisahkan oleh facility \\
\hline 15 & $\mathrm{~h}$ & $\begin{array}{l}\text { Ketidakpastian penaksiran deskripsi dan hasil (termasuk mengukur untuk mengatur } \\
\text { atau mengurangi ketidakpastian) }\end{array}$ \\
\hline 16 & $\mathrm{i}$ & $\begin{array}{l}\text { Deskripsi dan presentasi dari tambahan indikator (contohnya efisiensi atau } \\
\text { intensitas emisi GHG) }\end{array}$ \\
\hline 17 & j & Penaksiran dari kinerja terhadap benchmark internal dan atau eksternal \\
\hline 18 & k & Deskripsi dari GHG info management dan prosedur monitoring \\
\hline
\end{tabular}




\begin{tabular}{|c|c|c|}
\hline & BC1 & erubahan iklim: risiko dan peluang \\
\hline 19 & $(\mathrm{CC} 1)$ & $\begin{array}{l}\text { Penilaian atau deskripsi risiko dan/atau tindakan yang diambil atau akan diambil } \\
\text { untuk mengelola risiko perubahan iklim }\end{array}$ \\
\hline 20 & $(\mathrm{CC} 2)$ & Penilaian atau deskripsi terhadap implikasi keuangan saat ini (dan masa depan) \\
\hline 21 & & $\begin{array}{l}\text { Penilaian atau deskripsi peluang dari perubahan iklim untuk bisnis saat ini (dan } \\
\text { masa depan) }\end{array}$ \\
\hline \multirow[t]{2}{*}{22} & (CC4) & Informasi lain yang berkaitan dengan perubahan iklim \\
\hline & BBC2 & Akuntansi Gas Rumah Kaca (GRK) $\rightarrow$ lebih ke arah emisi yg dihasilkan \\
\hline 23 & (GHG3) & Jumlah total emisi gas rumah kaca \\
\hline 24 & (GHG4) & Pengungkapan emisi gas rumah kaca dari sumber (misalnya: batubara, listrik, dll) \\
\hline 25 & (GHG6) & Perbandingan emisi gas rumah kaca dengan tahun-tahun sebelumnya \\
\hline \multirow[t]{2}{*}{26} & (GHG7) & Informasi lainnya dari akur \\
\hline & BBC3 & Akuntan \\
\hline 27 & $(\mathrm{EC} 1)$ & Total Eners \\
\hline 28 & (EC2) & Kuantifikas \\
\hline 29 & (EC3) & $\begin{array}{l}\text { Pengungkapan penggunaan energi berdasarkan jenis (misalnya: batu bara, listrik, } \\
\text { dll) }\end{array}$ \\
\hline 30 & (EC4) & Pengungkapan penggunaan energi berdasarkan fasilitas atau tingkat segmen \\
\hline 31 & (EC5) & $\begin{array}{l}\text { Jumlah perbandingan konsumsi energi pada tahun sebelumnya atau pengurangan } \\
\text { level target }\end{array}$ \\
\hline \multirow[t]{2}{*}{32} & $(\mathrm{EC} 6)$ & lain tentang akuntansi konsumsi energi \\
\hline & BBC4 & s rumah kaca $\longrightarrow$ lebih kearah upaya pengurangan \\
\hline 33 & (RC3) & $\begin{array}{l}\text { jan emisi dan biaya yang terkait atau penghematan yang dicapai sampai } \\
\text { Jagai hasil dari rencana pengurangan }\end{array}$ \\
\hline 34 & $(\mathrm{RC} 4)$ & Biaya emisi masa depan diperhitungkan dalam perencanaan belanja modal \\
\hline \multirow[t]{2}{*}{35} & (RC5) & ngenai pengurangan gas rumah kaca dan biaya \\
\hline & BBC5 & Akuntabilitas emisi karbon \\
\hline 36 & (ACC1) & $\begin{array}{l}\text { Indikasi bahwa dewan komite atau badan eksekutif lainnya memiliki tanggung } \\
\text { jawab keseluruhan untuk tindakan yang berkaitan dengan perubahan iklim }\end{array}$ \\
\hline 37 & (ACC2) & $\begin{array}{l}\text { Deskripsi mekanisme para dewan atau badan eksekutif lainnya dalam meninjau } \\
\text { kemajuan perusahaan mengenai perubahan iklim }\end{array}$ \\
\hline
\end{tabular}

Debt Ratio merupakan tingkat penggunaan hutang suatu perusahaan. Debt ratio $=$ total debt/total asset (Sadeghian et al. 2012).

Non-Debt Tax Shield merupakan benefit pajak lainnya suatu perusahaan diluar dari beban bunga suatu hutang. Non-Debt Tax Shield $=$ depreciation/total assets (Kavitha 2014).

Metode statistik yang digunakan dalam pengujian hipotesis pada penelitian ini adalah dengan menggunakan multiple regression analysis. Adapun model persamaan linear berganda yang digunakan adalah sebagai berikut:

FIRMPER $=a+b_{1}$ GROWTH $+b_{2}$ FIRMSIZ + $b_{3} \mathrm{CASH}+\mathrm{b}_{4} \mathrm{AGE}+\mathrm{b}_{5} \mathrm{CARBON}+$ $b_{6}$ DEBT $+b_{7} N D T S+e$

Dimana:

$\begin{array}{ll}\text { FIRMPER } & =\text { Kinerja Perusahaan } \\ \mathrm{a} & =\text { Nilai Konstanta } \\ \mathrm{b} & =\text { Koefisien Regresi Linear } \\ \text { GROWTH } & =\text { Growth Opportunities } \\ \text { FIRMSIZ } & =\text { Firm Size } \\ \text { CASH } & =\text { Cash Ratio } \\ \text { AGE } & =\text { Firm Age }\end{array}$




$$
\begin{array}{ll}
\text { CARBON } & =\text { Carbon Credit } \\
\text { DEBT } & =\text { Debt Ratio } \\
\text { NDTS } & =\text { Non-Debt Tax Shield } \\
\mathrm{e} & =\text { Error }
\end{array}
$$

\section{HASIL PENELITIAN}

Berikut hasil statistika deskriptif untuk setiap variabel dan pengujian hipotesis dapat dilihat pada table berikut :

Tabel 3 Tabel Statistika Deskriptif

\begin{tabular}{lcccr}
\hline Variabel & Mean & Std. Deviation & Minimum & Maximum \\
\hline FIRMPER & 0.0386 & 0.0721 & -0.1907 & 0.2670 \\
GROWTH & 2.2585 & 3.0973 & 0.0030 & 18.8868 \\
FIRMSIZ & 6.2009 & 0.8858 & 4.0744 & 8.6643 \\
CASH & 0.7593 & 1.6818 & 0.0036 & 14.0622 \\
AGE & 32.87 & 8.188 & 15 & 59 \\
CARBON & 0.8000 & 0.3980 & 0 & 1 \\
DEBT & 0.4754 & 0.2246 & 0.0007 & 0.9431 \\
NDTS & 0.0308 & 0.0156 & 0.0010 & 0.0765 \\
\hline
\end{tabular}

Tabel 4 Hasil Uji Hipotesis

\begin{tabular}{lccc}
\hline Variabel & B & T & Sig \\
\hline Konstanta & -0.015 & -0.407 & 0.684 \\
GROWTH & 0.002 & 1.451 & 0.148 \\
FIRMSIZ & 0.021 & 4.355 & 0.000 \\
CASH & -0.002 & -0.576 & 0.565 \\
AGE & 0.001 & 1.155 & 0.249 \\
CARBON & -0.008 & -0.785 & 0.433 \\
DEBT & -0.170 & -7.637 & 0.000 \\
NDTS & -0.327 & -1.217 & 0.225 \\
\hline
\end{tabular}

Adjusted $R^{2}$ 0.287, $F_{14.094} 20.085$ Sig 0.000

Growth Opportunities (GROWTH) memiliki koefisien regresi sebesar 0.002 dengan nilai signifikan 0.148 lebih besar dari 0.05 . Hal ini menunjukkan bahwa hipotesis pertama tidak didukung. Hasil ini dapat timbul karena growth opportunities perusahaan yang diproksikan dengan MBV tidak mencerminkan secara langsung kinerja suatu perusahaan karena (MBV) harga saham dipengaruhi oleh supply dan demand para investor, kondisi perekonomian dan isu-isu mengenai perusahaan tersebut, sehingga growth opportunities tidak berpengaruh terhadap kinerja perusahaan.

Firm Size (FIRMSIZ) memiliki koefisien regresi sebesar 0.021 dengan nilai signifikan 0.000 lebih kecil dari 0.05 . Hal ini menunjukkan bahwa hipotesis kedua diterima. Hasil ini dapat timbul karena semakin tinggi firm size suatu perusahaan maka perusahaan tersebut memiliki dana yang besar untuk menghasilkan produk dalam jumlah yang besar, dengan produk yang dihasilkan dalam jumlah besar maka fixed cost lebih kecil karena unit yang dihasilkan lebih banyak dengan biaya tetap yang sama, dengan beban yang lebih kecil maka profit akan meningkat sehingga kinerja perusahaan meningkat. Selain itu sesuai dengan legitimacy theory perusahaan yang semakin besar akan lebih dipercaya oleh investor yang menyebabkan akses perusahaan dalam hal pendanaan akan lebih kuat karena investor akan lebih menginvestasikan dananya ke perusahaan tersebut sehingga pendanaan perusahaan 
tersebut dapat dikelola dengan menghasilkan profit lebih tinggi sehingga kinerja perusahaan akan lebih tinggi.

Cash Ratio (CASH) memiliki koefisien regresi sebesar -0.002 dengan nilai signifikan 0.565 lebih besar dari 0.05 . Hal ini menunjukkan bahwa hipotesis ketiga tidak didukung. Hasil ini dapat timbul karena cash ratio suatu perusahaan tinggi yang mengindikasikan kas dibandingkan hutang lancar yang tinggi tidak membuat perusahaan menghasillkan pendapatan lebih besar ataupun beban yang lebih kecil secara langsung, karena kinerja perusahaan lebih dipengaruhi langsung oleh bagaimana perusahaan tersebut menggunakan assetnya secara efektif dan efisien untuk menghasilkan pendapatan dan mengurangi bebannya, sehingga cash ratio tidak berpengaruh terhadap kinerja perusahaan.

Firm Age (AGE) memiliki koefisien regresi sebesar 0.001 dengan nilai signifikan 0.249 lebih besar dari 0.05 . Hal ini menunjukkan bahwa hipotesis keempat tidak didukung. Hasil ini dapat timbul karenafirm age tidak membuat suatu perusahaan menjadi lebih baik dalam hal pengelolaan perusahaan karena pengelolaan perusahaan lebih ditentukan top management yang dalam kepemimpinannya dapat membuat perusahaan berjalan secara efektif dan efisien dan faktor eksternal yaitu kondisi pasar diluar perusahaan yang berpengaruh terhadap kinerja perusahaan, sehingga firm age tidak berpengaruh terhadap kinerja perusahaan.

Carbon Credit (CARBON) memiliki koefisien regresi sebesar -0.008 dengan nilai signifikan 0.433 lebih besar dari 0.05 . Hal ini menunjukkan bahwa hipotesis kelima tidak didukung. Hasil ini dapat timbul karena carbon credit yang merupakan indikasi perusahaan mengurangi global warming dengan mengurangi konsumsi energi, mengurangi gas efek rumah kaca belum dilakukan secara optimal oleh perusahaan dan kurangnya pengungkapan dilaporan tahunan, sehingga carbon credit tidak berpengaruh terhadap kinerja perusahaan.
Debt Ratio (DEBT) memiliki koefisien regresi sebesar -0.170 dengan nilai signifikan 0.000 lebih kecil dari 0.05 . Hal ini menunjukkan bahwa hipotesis keenam didukung. Hasil ini dapat timbul karena debt ratio diproksikan total debt dibagi total asset, menunjukkan bahwa total debt yang semakin tinggi maka biaya bunga semakin tinggi pula yang mengakibatkan kinerja perusahaan semakin kecil, sebaliknya semakin rendah total debt maka biaya bunga semakin rendah yang mengakibatkan kinerja perusahaan semakin tinggi.

Non-Debt Tax Shield (NDTS) memiliki koefisien regresi sebesar -0.327 dengan nilai signifikan 0.225 lebih besar dari 0.05 . Hal ini menunjukkan bahwa hipotesis ketujuh tidak didukung. Hasil ini dapat timbul karena perusahaan yang memiliki non debt tax shield tidak serta merta menyebabkan kinerja perusahaan meningkat secara langsung, contohnya dengan beban penyusutan yang tinggi maka laba sebelum pajak lebih akan kecil sehingga beban pajak akan lebih kecil tetapi pengurangan beban pajak untuk meningkatkan laba bersih atau kinerja berkurang dengan tingginya beban penyusutan tersebut sehingga pengaruh terhadap kinerja perusahaan menjadi tidak signifikan.

\section{PENUTUP}

Growth opportunities tidak memiliki pengaruh terhadap kinerja perusahaan, hasil penelitian ini konsisten dengan hasil penelitian Seetanah et al. (2014), Bashir et al. (2013) dan Tariq et al.(2013) yang menemukan bahwa growth opportunities tidak berpengaruh terhadap kinerja perusahaan. Firm size memiliki pengaruh terhadap kinerja perusahaan, hasil penelitian ini konsisten dengan hasil penelitian Seetanah et al. (2014) menemukan bahwa size berpengaruh terhadap kinerja perusahaan. Hatem (2014), Abbas et al. (2013), Almajali et al. (2012), Bashir et al. (2013), Dwaikat dan Queiri (2014), Izati dan Margaretha (2014), Khalifa dan Shafii (2013), Mehari dan Aemiro (2013), Memon et al. 
(2010), Mirza dan Javed (2013), Pathirawasam dan Wickremasinghe (2012), Singh dan Dhingra (2013) dan Tariq et al. (2013) yang melakukan penelitian dengan hasil firm size berpengaruh secara positif dan signifikan terhadap kinerja perusahaan.Cash ratio tidak memiliki pengaruh terhadap kinerja perusahaan, hasil penelitian ini konsisten dengan hasil penelitian Bashir et al. (2013), Mehari dan Aemiro (2013) dan Tariq et al.(2013) yang menemukan bahwa liquidity ratio tidak berpengaruh terhadap kinerja perusahaan.

Firm age tidak memiliki pengaruh terhadap kinerja perusahaan, hasil penelitian ini konsisten dengan hasil penelitian Almajali et al. (2012), Mehari dan Aemiro (2013), Seetanah et al. (2014) dan Talebnia et al. (2010) yang menemukan bahwa firm age tidak berpengaruh terhadap kinerja perusahaan. Carbon credit tidak memiliki pengaruh terhadap kinerja perusahaan. Debt ratio memiliki pengaruh terhadap kinerja perusahaan, hasil penelitian ini konsisten dengan hasil penelitian Javed et al. (2014) yang menemukan bahwa debt to asset berpengaruh terhadap kinerja perusahaan.Tariq et al. (2013) yang menemukan bahwa short term leverage berpengaruh terhadap kinerja perusahaan. Izati dan Margaretha (2014), Singh dan Dhingra (2013), Memon et al. (2010) dan Pathirawasam dan Wickremasinghe (2012) yang menemukan bahwa leverage berpengaruh negatif terhadap kinerja perusahaan. Wahla et al. (2012) yang menemukan bahwa leverage memiliki hubungan negatif dan signifikan terhadap kinerja perusahaan. Non debt tax shield tidak memiliki pengaruh terhadap kinerja perusahaan.

Penelitian ini memiliki konsekuensi yang harus diteliti lebih lanjut karena penelitian dengan menggunakan carbon credit masih jarang dilakukan, selain itu hasil penelitian ini mempunyai hasil yang tidak signifikan antara carbon credit dengan kinerja perusahaan. Penelitian ini memiliki beberapa kekurangan dan keterbatasan penelitian sebagai berikut: sampel perusahaan yang digunakan terbatas pada perusahaan manufaktur dengan industry classification basic industry yang terdaftar di BEI sehingga hasil penelitian kurang dapat digeneralisasi; data variabel yang digunakan beberapa tidak berdistribusi normal, yaitu kinerja perusahaan, growth opportunities, firm size, cash ratio dan carbon credit. Adapun rekomendasi yang diberikan untuk penelitian selanjutnya adalah sebagai berikut: memperluas populasi penelitian dan tidak terbatas pada perusahaan manufaktur dengan industry classification basic industry tetapi industry classification lainnya yaitu agriculture, mining dan property, real estate and building construction; meneliti carbon credit dengan pengukuran yang berbeda tidak hanya menggunakan dummy variable tetapi menggunakan pengukuran kualitatif dan kuantitatif ataupun menggunakan dummy variable secara spesifik yaitu adanya pendapatan dari CER 0 atau tidak adanya pendapatan dari CER 1.

\section{REFERENSI:}

Abbas, Ali, Sahid Bashir, Shahid Manzoor, dan Muhammad Nadeem Akram. 2013. Determinants of Firm's Financial Performance: An Empirical Study on Textile Sector of Pakistan .Business and Economic Research. No. 2.

Almajali, Dr. Amal Yassin, Sameer Ahmed Alamro, Yahya Zakarea Al-Soub. 2012 . Factors Affecting the Financial Performance of Jordanian Insurance Companies Listed at Amman Stock Exchange .Journal of Management Research ,Vol. 4, No. 2.

Arkell, A. 2008. The Benefits of Assuring Carbon Emission Disclosures. Australia: The Institute of Chartered Accountants in Australia. 
Bashir, Sahid, Ali Abbas, Shahid Manzoor dan Muhammad Nadeem Akram. 2013. Empirical Investigation of the Factors Affecting Firm's Performance: a Study Based on Food Sector of Pakistan. International SAMANM Journal of Finance and Accounting, Vol. 1, No. 2.

Chu, C. I., Chatterjee, B. dan Brown, A. 2013. The current status of greenhouse gas reporting by Chinese companies A test of legitimacy theory. Managerial Auditing Journal, hlm.114-139.

Dowling, J. dan Pfeffer, J. 1975. Organizational legitimacy: social values and organizational behaviour. Pacific Sociological Review, 122-136.

Dwaikat, Nizar dan Abdelbaset Queiri. 2014. The Relationship between Ownership Structure and Firm's Performance: An Empirical Evidence from Palestine. International Journal of Business and Management, Vol. 9, No. 12.

Fachrudin, Khaira Amalia. 2011. Analisis Pengaruh Struktur Modal, Ukuran Perusahaan, dan Agency Cost Terhadap Kinerja Perusahaan. Jurnal Akuntansi Dan Keuangan, Vol. 13, №. 1, hlm.37-46.

Hatem, Ben Said. 2014. Determinants of Firm Performance: A Comparison of European Countries. International Journal of Economics and Finance, Vol. 6, No. 10.

Hastalona, Dina. 2013. Analisis Faktor-Faktor Yang Mempengaruhi Kebijakan Hutang. Jurnal Keuangan dan Bisnis, Vol. 5, No. 1, hlm.60-72.

Hidayat, M. 2013.IPOT NEWS. Retrieved December 25, 2013, from VIVA Web site: http://bisnis.news.viva.co.id

Izati, Chaerunisa dan Farah Margaretha. 2014. Faktor-Faktor Yang Mempengaruhi Kinerja Keuangan Pada Perusahaan Basic Industry And Chemicals Di Indonesia. E-Journal Manajemen Fakultas Ekonomi Universitas Trisakti ,Volume. 1 Nomor. 2 September , Hal. 21-43.

Javed, Tariq, Waqar Younas, Muhammad Imran. 2014. Impact of Capital Structure on Firm Performance: Evidence from Pakistani Firms. International Journal of Academic Research in Economics and Management Sciences, Vol. 3, No. 5.

Kavitha, R. 2014. Determinants of Capital Structure: Emprical Evidence from India. Indian Journal of Applied Research, Volume 4, Issue : 7.

Khalifa, Mohamed Khalifa dan Zurina Shafii. 2013. Financial Performance and Identify Affecting Factors in this Performance of Non-oil Manufacturing Companies Listed on Libyan Stock Market (LSM). European Journal of Business and Management, Vol.5, No.12.

Margaretha, F., \& Asmariani, A. 2009. FAKTOR-FAKTOR AGENCY THEORY YANG MEMPENGARUHI HUTANG. Media Riset Bisnis \& Manajemen, hlm.1-20.

Maryani. 2013. Regaining Company's Reputation: What is a Brand and Who Cares about Them? The Case Qantas. Jurnal IImiah ESAI.

Mehari, Daniel dan Tilahun Aemiro. 2013. Firm Specific Factors That Determine Insurance Companies Performance In Ethiopia. European Scientific Journal, Vol.9, No. 10.

Memon, Fozia ,Niaz Ahmed Bhutto dan Ghulam Abbas. 2010. Capital Structure and Firm Performance: A Case of Textile Sector of Pakistan .Asian Journal of Business and Management Sciences, Vol. 1 No. 9.

Mirza, Sidra Ali dan Attiya Javed. 2013.Determinants of Financial Performance of A Firm: Case of Pakistani Stock Market. Journal of Economics and International Finance, Vol . 5 (2) , pp 43-52.

Mondal, A. P. dan Scahdev, S. 2012. Carbon Credit: A Burning Business Issue. The Business \& Management Review, 170-178.

Pathirawasam, Chandrapala dan Wickremasinghe, Guneratne. 2012. Ownership Concentration and Financial Performance: The Case Of Sri Lankan Listed Companies. Corporate Ownership \& Control, Volume 9, Issue 4.

Pratiwi, Putri Citra dan Sari, Vita Fitria. 2016. Pengaruh Tipe Industri, Media Exposure dan Profitabilitas terhadap Carbon Emission Disclosure. Jurnal WRA, Vol.4, No.2, hIm. 829-843.

Rankin, M., Windsor, C. dan Wahyuni, D. 2011. An investigation of voluntary corporate greenhouse gas emissions reporting in a market governance system Australian evidence. Accounting, Auditing \& Accountability Journal, Vol. 24, No.28, hlm.1037-1070. 
Romagos, C. P., Almenar, K. Q., Singson, A. F., \& Sio, M. J. 2012. CORPORATE DEBT FINANCING IN THEPHILIPPINES: EXAMINING THE ROLE OF FIRM-LEVEL FACTORS THROUGH BINARY CHOICE MODEL. Journal of International Business Research, 105-120.

Sadeghian, N. S., Latifi, M. M., Soroush, S., \& Aghabagher, Z. T. 2012. Debt Policy and Corporate Performance: Empirical Evidence from Tehran Stock Exchange Companies. International Journal of Economics and Finance, 217-224.

Sanjaya, Riki. 2014. Variabel-Variabel yang mempengaruhi Kebijakan Hutang. Jurnal Bisnis dan Akuntansi, Vol.16, No.1, Juni 2014, hlm.46-60.

Salawu, R. O., Asaolu, T. O., \& Yinusa, D. O. 2012. Financial Policy and Corporate Performance: An Empirical Analysis of Nigerian Listed Companies. International Journal of Economics and Finance.

Singh, Fulbag dan Priyansha Mahajan Dhingra. 2013. Sub-prime Crisis: Analyzing Corporate Financial Performance Under Panel Data Estimation. Asia-Pacific Finance and Accounting Review, Volume 1, No. 2.

Seelanatha, Lalith. 2011. Determinants of Firms' Performance: Some Chinese Evidence. Investment Management and Financial Innovations, Volume 8, Issue 3.

Seetanah, Boopen, Keshav Seetah, Kevin Appadu, K Padachi. 2014. Capital Structure And Firm Performance: Evidence From An Emerging Economy. The Business \& Management Review, Volume 4 Number 4.

Tariq, Waqas, Imran Ali, Hafiz Muhammad Usman, Jawad Abbas, dan Zahid Bashir. 2013. Empirical Identification of Determinants of Firm's Financial Performance: a Comparative Study on Textile and Food Sector of Pakistan Business and Economic Research, Vol. 3, No. 1.

Talebnia, Ghodratallah, Mahdi Salehi, Hashem Valipour dan Shahram Shafiee. 2010. Empirical Study of the Relationship between Ownership Structure and Firm Performance: Some Evidence of Listed Companies in Tehran Stock Exchange. Journal of Sustainable Development, Vol. 3, No. 2.

Vijn, S., Schrijver, C., Buck, B., Haagsma, W., Dijk, A. V., Elsen, M., et al. 2007. Reporting the Business Implications of Climate Change in Sustainability Reports. Netherlands: KPMG Global Sustainability Services and the Global Reporting Initiative.

Wahla, Khalil-Ur-Rehman, Syed Zulfiqar Ali Shah, and Zahid Hussain. 2012. Impact of Ownership Structure on Firm Performance Evidence from Non-Financial Listed Companies at Karachi Stock Exchange. International Research Journal of Finance and Economics, Issue 84.

Wijaya, Novia. 2012. Pengaruh Intellectual Capital Terhadap Kinerja Keuangan Dan Nilai Pasar Perusahaan Perbankan Dengan Metode Value Added Intellectual Coefficient. Jurnal Bisnis Dan Akuntansi, Vol. 14, No. 3, hlm. 157-180.

Wiranata, Yulius Ardy, Nugrahanti, Yeterina Widi. 2013. Pengaruh Struktur Kepemilikan Terhadap Profitabilitas Perusahaan Manufaktur di Indonesia. Jurnal Akuntansi dan Keuangan, Vol. 15, No. 1, hlm.15-26. 